\title{
Research about problems of improving the financing-difficulty issue for small, medium and micro-sized enterprises based on the perspective of city commercial banks in the dual circulation background
}

\author{
Xinlong Zhao ${ }^{1, *}$, Shengnan $\mathrm{Qi}^{2}$, Yutong Song ${ }^{3}$, and Yining Chen ${ }^{4}$ \\ ${ }^{1}$ Department of Finance, Inner Mongolia University, Saihan District, Hohhot, Inner Mongolia, China \\ ${ }^{2}$ Department of Finance, Inner Mongolia University, Saihan District, Hohhot , Inner Mongolia, China \\ ${ }^{3}$ Department of Finance, Inner Mongolia University, Saihan District, Hohhot, Inner Mongolia, China \\ ${ }^{4}$ Department of Finance, Inner Mongolia University, Saihan District, Hohhot , Inner Mongolia , China
}

\begin{abstract}
In order to solve the current financing-difficulty issue for small, medium and micro-sized enterprises, in the "two sessions" of 2021 , government has released various favoring policies regards the development of small-sized enterprises, and predictably, in the future small, medium and micro-sized enterprises could combine with more and more policy advantages to achieve sustainable progress . As local financial institution, city commercial banks as well undertakes the responsibility of providing financial supports for small, medium and micro-sized enterprises and laying out the fundamental basis for local economy . This article will initiate from functions of our national city commercial banks in financing for small, medium and micro-sized enterprises, then respectively analyse the current situation of both small, medium and micro-sized enterprises financing and city commercial banks, bring up challenges that city commercial banks confront in the progress of business of financing for small, medium and micro-sized enterprises, and offer suggestions concerning promoting our national city commercial banks' financing business and measures to deal with existing issues. At the end, based upon the development orientation of city commercial banks, provide optional measures aimed to ameliorate the financing-difficulty issue of our national small, medium and micro-sized enterprises.
\end{abstract}

\section{Introduction}

As regional financial institution, regional bank, city commercial bank is of the same nature compared with other commercial bank, while the difference is that the former only serves for the specific locality where it is . Given the gradual stabilization of economic foundation, there has been an increasing concentration on the level of progress of regional economy. For there are numerous of regional private small, medium and micro-sized enterprises, they formed a major contribution to national economy and advance of society . The $14^{\text {th }}$ five-year prospect plan and proposition of objective for 2035 made by CCCP , concerning national economy and advance of society , suggests that we should ameliorate the development environment for private economy, establish an affine but with principle, incorruptible but capable of achievements relationship between government and businessmen, encourage the sound development of non-public economy and businessmen, legally and equally protect property right of private enterprises and entrepreneurs, eradicate all existing inhibitions on the development of private enterprises and consummate legal background and policy system for small, medium and micro-sized enterprises and individual business . Additionally, the report on the government work in the "two-sessions" of 2021 mentions great deal about supportive measures about protecting economy and people's livelihood, and it indicates that small, medium and micro-sized enterprises are indispensable in terms of employment, economic vigour and meeting residents' requirement . But, opportunities coexist with challenges, at the moment of the expanding of credit assets of city commercial bank, some issues are emerging and confronting the development of city commercial bank itself. As for that, the only solution is coming up with options specifically designed for city commercial banks, and thus effectively figuring out the method of solving the financing-difficulty problem of small, medium and micro-sized enterprises .

The development of economy is the fundamental base of finance, for the local economy prospers well, it exerts a positive influence upon City Commercial Banks , bringing greater financial support to the progress of small, medium and micro-sized enterprises. While there exist problems such as faultiness of the management system of

*Corresponding author: maxxinlong@163.com 
City Commercial Banks, monotonicity of transaction technique and lack of capacity for the update of products, etc., the survival and stretching out of City Commercial Banks are both inhibited, and thus so is the development of small, medium and micro-sized enterprises .

\section{Functions of city commercial banks in financing operations for small, medium and micro-sized enterprises}

Ever since the Reform and Opening-up, the economic base level of the city has become an important evaluation component affecting the quality of life of the people. In order to better play its role in promoting the regional economy, the State Council agreed to establish a city commercial bank, so that the city has a financial institution suitable for its own urban economic development. Thus further accelerated the development of socialist market economy .

Last century, city commercial bank plays an irreplaceable role in development of regional economy, yet, till the end of century, due to lasting unscientific management and also untrained employees, the advance of city commercial bank has been hindered. In the beginning of 21 st century then, under the effort of both People's Bank of China and CBRC, city commercial banks increased their investment and reformed its ownership structure in a way such that it motivates both national and international capital to invest. Therefore, the operation management ability has been raised, consequently offering better financial services to our national small, medium and micro-sized enterprises . In April , 2009 , the country loosened limitations on city commercial banks, while allowing qualified commercial banks set up branches, free from quantity control . In October , 2015 , our country brought up five major development belief, innovation, compatibility, green, open-up and sharing, of which city commercial banks took advantage and eagerly consulted with local government to obtain policy support . Hence, city commercial banks are capable of being accurately informed about information of local small, medium and micro-sized enterprises and then strengthen risk protection ability .

The " city commercial banks' growth report of 2020 " issued by working committee of city commercial banks of China Banking Association points out, the overall growth rate of assets has been steady, the structure of asset and liability has improved and the risk protection ability has enhanced. Till the end of 2019 , 134 city commercial banks' amount of total assets is 37.3 trillion , $8.5 \%$ rate of growth compared to the beginning of the year, loan balance 17.6 trillion , $18.4 \%$ rate of growth compared to the beginning of the year, twice as the rate of growth of assets, total liability 34.5 trillion , 8.4\% rate of growth compared to the beginning of the year, in which deposit balance has a proportion of $68.5 \%$, inter-bank liability $12.3 \%$, the structure of liability is getting better . Net profit 250.9 billion , $2 \%$ rate of growth compared to the beginning of the year.
The ratio of non-performing loans $2.3 \%$, provision coverage $154 \%$, Capital adequacy ratio $12.7 \%$. Till the end of August of 2019 , the number of small-sized enterprises borrowing is 20.4761 million , $18.8 \%$ rate of growth compared to the beginning of the year, has increased 3.2427 million, loan balance 10.94 trillion, increased 1.58 trillion compared to the beginning of the year, and $8.15 \%$ over the rate of growth of others kinds of loans. Over the last few years, through improving its own structure and practiced cross-region cooperation, bonding both internal and external cooperation, city commercial bank steadily grow up in capital, as well as in assets and market proportion, profoundly supportive local small, medium and micro-sized enterprises' financing and making greater contribution to the growth of regional economy . Deserving the reputation, city commercial bank give essential assistance to the financial service for small, medium and micro-sized enterprises and constructed main structure of regional financial system , elevating our national banks' system structure, filling the faultiness of financial service and giving support to the growth of small, medium and micro-sized enterprises in our country .

\section{The present situation of financing of small, medium and micro-sized enterprises in our country}

With the gradual growth of our national economy, private small and medium-sized enterprise is indispensable no matter in terms of growth of national economy, contribution to GDP , offering employment opportunities or people's livelihood. But, there are all sorts of constrictions to its growth. Just as the second research report about small-sized enterprises, by CMB, reveals in figure 1 that when it comes to enterprises' financing, the major difficulty that confronts it is the overwhelming pressure of making the repayment punctually , 49.8\%, and expensive cost for financing , 39.6\% . Except for these , approximately twenty-percent of small-sized enterprises face problems, such as tight credit requirement, inefficiency and deficiency, etc. Therefore, being aware of the present situation of financing of small, medium and micro-sized enterprises in our country is the task of priority to solve the financing-difficulty issue .

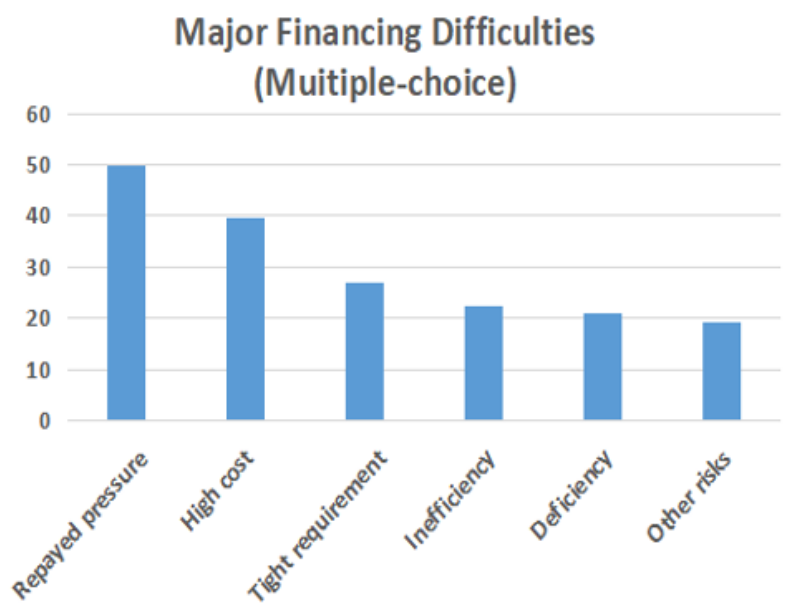

Fig. 1. Difficulties in financing small and micro enterprises 


\subsection{Monotonic financing technique}

At present, the primary financing method for small, medium and micro-sized enterprises in our country is the credit fund of banks. Since 2020 , in one of the enterprise zones , 12 enterprises has a total loan balance of 398 million, and 6 of them is borrowing from one bank , 3 of them are borrowing from two banks, the other 3 of them are borrowing from three or more than three banks. It suggests small, medium and micro-sized enterprises rely heavily on the credit fund of banks .

\subsection{Expansive cost for financing, and inflexibility of financing}

While the macro-environment has been deteriorating, there has been amplified financing cost for small, medium and micro-sized enterprises compared to the previous . Currently, the financing cost for small, medium and micro-sized enterprises principally composed of interest and transaction cost. On the one hand, banks charge the interest of enterprise loan conditionally on enterprises' overall qualification, thus charging higher interest as generally small, medium and micro-sized enterprises are small in scale, their financial statements are incomplete, also the condition of their assets is hard to be valued. On the other hand, although the transaction cost of enterprise financing is fixed, which means the unit capital transaction cost goes down as the amount of financing increases, small, medium and micro-sized enterprises usually seek for less money, use it for short period of time, resulting in relatively high transaction cost contrasted to large enterprises. What's more, in the process of financing for small, medium and micro-sized enterprises , because of informative asymmetry, it is much more probable that they go through morality risks. Additionally, the over-complicated approving process of bank costs great amount of time. According to the data of 2014 , the interest of bank loan for small, medium and micro-sized enterprises is around $10 \%$ to $15 \%, 18 \%$ for huge amount of loan in private lending, exceedingly higher than the cost for large enterprises [1].

\subsection{Credit problem results in more risk for financing}

For guarantee problem, the financing of small, medium and micro-sized enterprises is further inhibited With lower asset liability ratio, more appropriate portfolio of debt deadline, the enterprises pays lesser cost for financing and less riskily. However, for small, medium and micro-sized enterprises, their ratio of fixed asset is low, the ability to realize is weak, yet asset liability ratio is high, then consequently they end up with a few available collateral but great risk. Also ,small , medium and micro-sized enterprises survive a short period of time, as well the debt maturity . According to Fortune Magazine, in United
States, small, medium and micro-sized enterprises averagely exist less than 7 years, while in China, only 2 years and a half. Annually there are about 100 thousand of enterprises that go bankrupt in US, but there are 1 million of them in China, tenfold as US . Not only that they exist shortly, there are just few of them could grow big.

Besides, the "financial service report for small, medium and micro-sized enterprises in China" issued by People's Bank of China and CBIRC indicates that till the end of 2018 , defective ratio of debt for the legal representatives of small, medium and micro-sized enterprises is $3.16 \%$, for loan amount below 5 million $5.5 \%$, till the end of May of 2019 , for loan amount below 10 million $5.9 \%$. In addition to that, Central Bank Paper mentions that mainly for the faultiness of current social credit system and business environment, our country dedicates to work on financial service for small, medium and micro-sized enterprises . Given the average period of existence of small, medium and micro-sized enterprises, financial institutions are challenged by higher risks in offering financial services to them .

\section{Current growth situation of city commercial banks in China}

Small and medium-sized enterprises have always been the target market for financial services of city commercial banks in China . From 1995 to now , more than 100 city commercial banks have been located in different regions, providing strength guarantee for local economy and long-term growth of small and medium-sized enterprises [2]. Since the Two Sessions in 2021 , it is necessary to pay attention to the development of city commercial banks in order to better deepen and expand the loan model of small and medium-sized enterprises in China, support small and medium-sized enterprises and help our economy to recover .

\subsection{Assets and liability scale}

As the table $1 \& 2$ shows, from 2019 to 2020 , both total assets and total liabilities of city commercial banks have increased remarkably. The amount of capital among banking financial institutions makes a ratio from $11.56 \%$ to $12.41 \%$, bringing its core advantage into play. The contrast between table 1 and 2 reveals that, in the first and second quarters of 2020 , asset liability ratio has dropped compared to the same period of previous year, while in the third and fourth higher. In total, city commercial banks' assets and liability are increasing at a stable rate.

Table 1. Quarterly assets and liabilities of CCB in 2020

\begin{tabular}{|c|c|c|}
\hline & $\begin{array}{c}\text { Total } \\
\text { Assets(Bil) }\end{array}$ & $\begin{array}{c}\text { Total } \\
\text { Liabilities(Bil) }\end{array}$ \\
\hline First quarter & 38139.3 & 35251.1 \\
\hline
\end{tabular}




\begin{tabular}{|c|c|c|}
\hline $\begin{array}{c}\text { Year-on-year } \\
\text { growth rates }\end{array}$ & $8.3 \%$ & $8.1 \%$ \\
\hline Second quarter & 39560.8 & 36603.6 \\
\hline $\begin{array}{l}\text { Year-on-year } \\
\text { growth rates }\end{array}$ & $10.0 \%$ & $9.8 \%$ \\
\hline Third quarter & 40285.2 & 37297.7 \\
\hline $\begin{array}{l}\text { Year-on-year } \\
\text { growth rates }\end{array}$ & $11.7 \%$ & $11.7 \%$ \\
\hline Fourth quarter & 41069.9 & 38154.0 \\
\hline $\begin{array}{l}\text { Year-on-year } \\
\text { growth rates }\end{array}$ & $10.2 \%$ & $10.6 \%$ \\
\hline
\end{tabular}

Date sources : CBIRC website .

Table 2. Quarterly assets and liabilities of CCB in 2019

\begin{tabular}{|c|c|c|}
\hline & Total Assets(Bil) & $\begin{array}{c}\text { Total } \\
\text { Liabilities(Bil) }\end{array}$ \\
\hline First quarter & 35226.9 & 32619.5 \\
\hline $\begin{array}{l}\text { Year-on-year } \\
\text { growth rates }\end{array}$ & $11.53 \%$ & $11.29 \%$ \\
\hline Second quarter & 35976.7 & 33328.9 \\
\hline $\begin{array}{l}\text { Year-on-year } \\
\text { growth rates }\end{array}$ & $11.28 \%$ & $11.17 \%$ \\
\hline Third quarter & 36071.4 & 33389.9 \\
\hline $\begin{array}{l}\text { Year-on-year } \\
\text { growth rates }\end{array}$ & $9.00 \%$ & $8.84 \%$ \\
\hline $\begin{array}{l}\text { Fourth quarter } \\
\text { Year-on-year } \\
\text { growth rates }\end{array}$ & 37275.0 & 34497.4 \\
\hline
\end{tabular}

Date sources : CBIRC website .

\subsection{Capital adequacy ratio}

Depending on the capital adequacy ratio of city commercial banks, large commercial banks and foreign banks over the whole year in 2019, published by CBRC, the capital adequacy ratio of city commercial banks increase or decrease in line with the one of banking financial institution, but meanwhile lower than the average level . Overall, it suggests the weak capacity against risk of city commercial banks and higher risks .
In conclusion, there is much to improve in terms of capital adequacy ratio [3] .

Table 3. Comparison of capital adequacy ratio of three major commercial banks in 2019

\begin{tabular}{|c|c|c|c|c|}
\hline & $\begin{array}{c}\text { First } \\
\text { quarter } \\
(\%)\end{array}$ & $\begin{array}{c}\text { Second } \\
\text { quarter } \\
(\%)\end{array}$ & $\begin{array}{c}\text { Third } \\
\text { quarter } \\
(\%)\end{array}$ & $\begin{array}{c}\text { Fourth } \\
\text { quarter } \\
(\%)\end{array}$ \\
$\begin{array}{c}\text { City } \\
\text { Commercial }\end{array}$ & 12.64 & 12.43 & 12.51 & 12.70 \\
Bank & 15.67 & 15.66 & 16.18 & 16.31 \\
\hline $\begin{array}{c}\text { Large } \\
\text { Commercial }\end{array}$ & & & & \\
\hline Bank & & & & \\
\hline Foreign Bank & 18.31 & 18.21 & 18.28 & 18.40 \\
& & & & \\
\hline
\end{tabular}

Date sources : CBIRC website.

\subsection{Risk profile}

As the data from 2018 to 2020 reports, non-performing loan ratio [4] of city commercial banks keeps increasing year after year. Through out each quarter , non-performing loan ratio of city commercial banks is higher than that of large commercial banks, which regarding regional banks could be a tremendous negative influence. The higher non-performing loan ratio of city commercial banks, more likely unable to retrieve and more risky consequences. It also affects the profit of banks, since they wouldn't be able to aid local medium-sized enterprises. Thus, city commercial banks need to strengthen on risk management aspect .

Table 4. Non-performing loan ratio of large commercial banks , 2018-2020

\begin{tabular}{|c|c|c|c|c|}
\hline & First & Second & Third & Fourth \\
& quarter & quarter & quarter & quarter \\
\hline 2020 & $1.39 \%$ & $1.45 \%$ & $1.50 \%$ & $1.52 \%$ \\
\hline
\end{tabular}




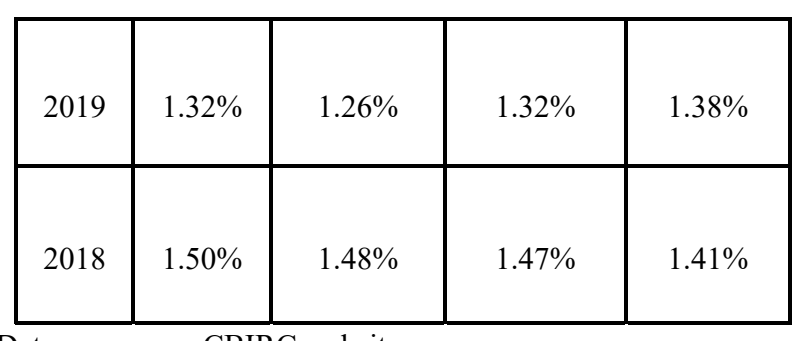

Date sources : CBIRC website .

Table 5. Non-performing loan ratio of city commercial banks, 2018-2020

\begin{tabular}{|c|c|c|c|c|}
\hline & $\begin{array}{c}\text { First } \\
\text { quarter }\end{array}$ & $\begin{array}{c}\text { Second } \\
\text { quarter }\end{array}$ & $\begin{array}{c}\text { Third } \\
\text { quarter }\end{array}$ & $\begin{array}{c}\text { Fourth } \\
\text { quarter }\end{array}$ \\
\hline 2020 & $2.45 \%$ & $2.30 \%$ & $2.28 \%$ & $1.81 \%$ \\
\hline 2019 & $1.88 \%$ & $2.30 \%$ & $2.48 \%$ & $2.32 \%$ \\
\hline 2018 & $1.53 \%$ & $1.57 \%$ & $1.67 \%$ & $1.79 \%$ \\
\hline
\end{tabular}

Date sources : CBIRC website .

\subsection{Profit profile}

Over the four quarters of 2020 , profit rate of city commercial banks are, respectively , $0.81 \%, 0.74 \%$, $0.66 \%, 0.55 \%$, while for large commercial banks , $1.02 \%, 0.88 \%, 2.88 \%, 2.89 \%$. In 2020 , the return on capital of city commercial banks is lower than that of large commercial banks, suggesting a lower investment profit and higher investment risk, not in favor with the growth of city commercial banks .

In other words, in the four quarters of 2020 , the net interest difference of urban commercial banks is $2.00 \%$, $2.00 \%, 1.99 \%$ and $2.00 \%$ respectively , and the net interest difference of large commercial banks is $2.04 \%$, $2.03 \%, 2.05 \%$ and $2.03 \%$ respectively . There is a gap between the two, but not very large, which can increase the difference between deposit and loan to increase interest income, which shows that urban commercial banks still have great potential in net interest margin. The increase of the net interest difference of the city commercial bank symbolizes that it can promote the transformation and upgrading of the local economy and realize the integration and interaction with the local real economy, which has made an important contribution to the development of the local small and medium-sized enterprises and the national tax revenue.

\section{SWOT analyse of city commercial banks in terms of financing small, medium and micro-sized enterprises}

\subsection{The strength}

Being a regional financial institution allows city commercial bank be capable of, at very first moment, getting informed with operational necessity of local small, medium and micro-sized enterprises and thus capable of providing appropriate financial services to them . For different regions' economy grows at different rate, as well as the development level of each small, medium and micro-sized enterprises, city commercial banks take advantages of having access to information about financial status, development of project and credit status of debtors [5], so that it could economize middle processes , minimize decision policy, save time and make progress to economy .

\subsection{The weakness}

Among the majority of city commercial banks, there is negative profit growth . Those are the ones are struggling with serious deficit, disorganized management and being incapable of undertaking risks, finding themselves on the edge of insolvency and bankruptcy ahead. Learned from previous experience, most of their recovery assets are the investments located everywhere abroad or in out-of-reaching areas. Since city commercial banks don't always have branch offices beside its own city, it couldn't recover those debt on time, and it definitely will bring exceedingly additional cost to assets management if they search for the help of banks outside the city . As a result, the only approach they could take is to auction those fixed assets cheaply, way much lower than the market price, result in heavy lost for city commercial banks .

Most of the small, medium and micro-sized enterprises finance by the means of legal entity credit loan, the operation business of which is a highly professional work. It has a critical requirement for the professional quality of related employees, not only being familiar with basic knowledge, but also knowledge about financial analysis and management are necessary. However, city commercial banks are in shortage of those professionals with such ability .

\subsection{Opportunities}

Moving alongside with continuous growth of economy, small, medium and micro-sized enterprises spring up one after another, being influential in aspects of growth of regional economy, employment, technology innovation and people's livelihood. Momentarily, it is quite a task for small, medium and micro-sized enterprises to obtain credit fund from state-owned banks, and the financing-difficulty is the real inhibition to its growth . The turning point was that a series of supportive policies for them was published in the government work report of 
"two sessions" of 2021 , including raising the the minimum threshold for small-scale VAT taxpayer from 100 thousand of monthly sale to 150 thousand, lowering $10 \%$ of charge of broadband for them , continuing $75 \%$ additional deduction for R\&D expense and $100 \%$ specifically for manufacture enterprises . In line with all these policies, it could be inspiring opportunity for city commercial bank to loosen credit operation requirement to finance mall and medium-sized enterprises . By practicing appropriate measures, it could aid small, medium and micro-sized enterprises moving out of dilemma and reach to a win-win situation .

From another perspective, the twelfth of the $4^{\text {th }}$ national economic census serial report states, the overall scale of small, medium and micro-sized enterprises has kept expanding, till the end of 2018 , there are , in total , 18.07 million legal entities of them and has increased 9.664 million since end of 2013 , $115 \%$. Their ratio of all kinds of enterprises legal entity is $99.8 \%$, increased $0.1 \%$ since the end of 2013 , and among them , there are 239 thousand large enterprises , $1.3 \%, 239.2$ thousand small enterprises , $13.2 \%$, micro-sized enterprises 15.439 million , 85.3\% . Suggested by figure 2 , among all-scale enterprises , small , medium and micro-sized enterprises has a much larger borrowing need index than large ones .

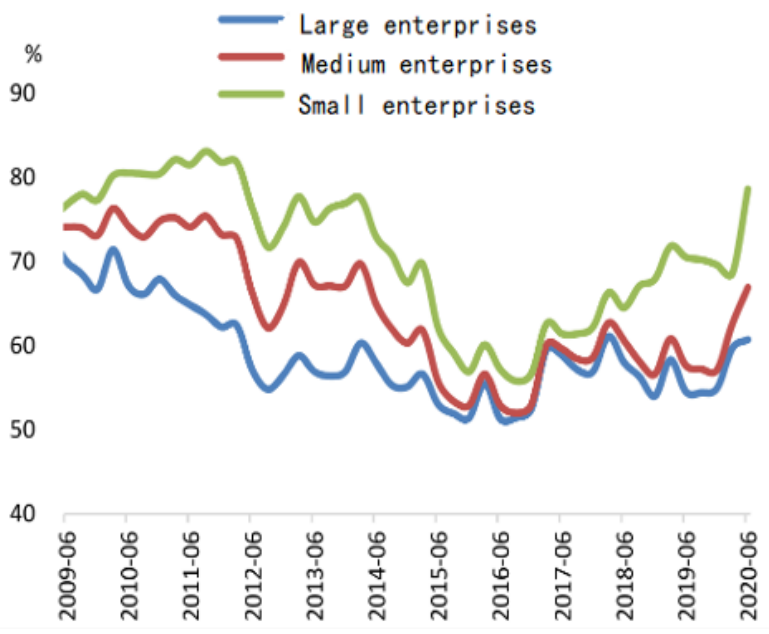

Fig. 2. Large, medium and small enterprises loan demand index 2009-2020

Not only growing in overall scale, accompanied by the improvement of business environment, private enterprises are also digging out all their potential, rapidly advancing. Till the end of 2018 , there are 15.265 million small, medium and micro-sized private enterprises, has increased 954.6 thousand since the end of $2013,166.9 \%$, and share $84.4 \%$ out of all enterprises, has increased $16.5 \%$ since the end of 2013 . Among them, there are 1359.1 thousand Pte Ltd, $75.1 \%$, has increased 972.7 thousand sine the end of $2013,251.8 \%$, way much faster than the growth rate of all small, medium and micro-sized enterprises legal entity over the same period. Also, it's predictable that along national encouragement toward college students starting their own business, the number of small, medium and micro-sized enterprises will increase even more faster in a while .

\subsection{Threats}

City commercial banks is living with threats from both within and without the country. Internally, being treated diversely than state-owned commercial banks and joint-stock commercial banks, although without real difference in nature and in operation ability, there exists an insuperable gap in terms of the arrangement for the distribution of institutions . City commercial banks is weak in stretching out, grounded to its own region and also pressed from all sides. Externally, under the opening-up condition of international economy, the growing international cooperation brings in more powerful foreign banks, who compete against local banks aggressively .

The increase of quantity of small, medium and micro-sized enterprises creates not only chances, but also challenges to city commercial banks . Due to faultiness such as the problematic legal entity credit risk management, irresponsibility of account managers , unbalanced concentration on the quantity of credit loan instead of quality, as well incapacity to estimate risks of credit, after the loan issued, some debtors wouldn't even be able to pay back neither principal nor interest in deadline .

\section{Problems exist in financing operations of city commercial banks for small, medium and micro-sized enterprises in China}

\subsection{In terms of risk management ability}

Risks exist for city commercial banks as well . In China, the issues of the risk management system of them contain both internal and external reasons. Internally, first, their banking business is sole targeted toward the support for the regional finance, lack effective and in-time risk protection ability, for its target is relatively limited in a range, and it cannot disperse risks and decrease the possibility for their occurrence. Secondly, the concept of risk management is rather outdated, and still applies credit risk management and omits practical factors and the risk variable of the market, causing the increase for uncertainties and eventually leading to increase of risk . The third reason is that the risk management risk is quite incomplete, falls behind a comprehensive scientific management system, lacks the ability of objective judgment and predictable idea, so that it could not be an independently objective individual and could easily be influenced by accidental situations .

Externally, the credit system is not yet established completely, cannot form an effective information net, blocking out many small, medium and micro-sized enterprises from business because of shortage of capital . Then banking information is always postponed and incomplete to some degree, without a standard norm, 
although there are external supervision and restrain from the market. But in terms of the growth of city commercial banks, the oversimplification of supervision measures and incompleteness of the function of market restrain impose an inhibition upon the growth of them, and have a negative outcome .

\subsection{In terms of innovation of financial products}

As for city commercial banks, it is insufficient to provide financial support only for traditional small, medium and micro-sized enterprises . With various and distinct small, medium and micro-sized enterprises emerging in the market, city commercial banks ought to design more innovative financial products , specifically aimed to expand financial business for them .

Furthermore, city commercial banks have the deficiencies of creative concept for new financial products, using intelligent for business, such as financial services, assets appraisals, etc., which makes them end up giving up greatly potential profitable business, and unable to increase profits further.

\subsection{Deficiency in professionals' training}

In the ever-increasingly intense competition, city commercial banks are organized in a client-centred manner, promote one-stop services, offering various businesses and services for all sorts of clients. This requires talented employees who are capable of serving both traditional and innovative businesses . Due to the incompleteness of current organization management system, and the incapacity of distinguishing small, medium and micro-sized enterprises, of investigating trust degree and of risk management, and variousness and different procedure change means of innovative businesses, there is huge weakness on perspectives of training professional employees, inhibiting the long-term growth of city commercial banks and creating an obstacle on the way of the growth of small, medium and micro-sized enterprises .

\subsection{Inefficiency in financing small, medium and micro-sized enterprises, procrastinated approval of loan}

In China, procedures of loan for small, medium and micro-sized enterprises are unbelievably intricate and trivial, thus requiring a long period of time for approval . Especially, those specific departments designed for small, medium and micro-sized enterprises are so rare that there are only a few of them across the whole country. This leads to the long loan cycle of most small and medium-sized enterprises in China, and the high manpower and material resources and time cost during this period.

\section{Advice for city commercial banks upon promoting finance business for small, medium and micro-sized enterprises}

\subsection{Strengthen risk management ability, avoid asset risk}

(1) Establish preventive idea, strengthen individual avoid risk ability . City commercial bank is in a highly risky field, being exposed to the worldwide economic revolution, it ought to improve its own risk management level, by starting out from the trifle, watching out for risks from all places, learning from experiences and keeping the economic system abundant. Also, it should foster employees by means of lecture or training, so that it will have a firmly executive framework inside and comprehensive ability to handle asset risk .

(2)Build up the risk protection model for the practical purpose, sharpen tasks of department. The multiple uncertainties in the economic revolution background requires a risk protection framework, which deals with issues at very first place and save resources . Emphasize corresponding responsibility for each individual department, make sure that they separately practice their function, yet always ready to joint up and interconnect with each other in order to set up the first detection spot for risks as business department .

\subsection{Implement cross-region cooperation, give its own advantage into play}

While guaranteeing motivation for regional economy and financial services for small, medium and micro-sized enterprises, city commercial bank should break the limitation of traditional business and expand beyond its own region. Taking advantage of being thoroughly familiar with profile of regional enterprises, city commercial bank could offer properly loan of low interest for small, medium and micro-sized enterprises and solve capital shortage problem. Meanwhile, city commercial bank could spread out its business region broad, compete against other commercial banks, give full play to own advantages, so as to change the original business model .

\subsection{Work on innovating ability instead of following passively}

It is an urge for city commercial bank to get to know about demands of the latest small, medium and micro-sized enterprises in order to offer customized service and stay competitive [6]. For example, if the client seeks for deposit operation, it could initiate online operation service and launch convenient payment method to meet the need of client . Also, it could search for more channels of financing by designing brand-new financial products, which covers both capital and monetary market . 


\subsection{Develop specialized professionals, realize customized service}

In line with the progress of financial market, business of city commercial bank has also kept making breakthrough through out counter service, e-bank and mobile bank, which in return requires plenty of maintain work performed by professional [7], therefor it becomes necessary to develop those professionals .

(1) Educate professional knowledge , and teach employees corresponding to their own character . Put effort into specific and designed training for employees provide additional tutors for those without theoretical knowledge as backup, and provide advanced training for those already well-educated .

(2) Construct a scientific test and evaluation system for employees [8], which would enable city commercial bank to explore potential ability of employees and allow those with talent deserve better chance .

\subsection{Meliorate organization structure, enhance efficiency of management}

Every single city commercial bank ought to emphasize and enlarge their service toward small, medium and micro-sized enterprises, found independent department that only serves them, accompanied with specially risk management, carry out particular credit plan for them and contrive related favourable policies . It also should elaborate its department structure so that small, medium and micro-sized enterprises could have direct access to the face-to-face financing service and to the simplified procedure .

\section{Ways of improving the financing issue of small, medium and micro-sized enterprises based on the perspective of city commercial banks' growth orientation}

\subsection{Establish proper relationship with city commercial banks}

Based on the growth orientation of reinforcing risk management ability and evading risky assets of city commercial bank, small, medium and micro-sized enterprises can set up a friendly relationship with local city commercial banks. For city commercial bank has the flexibility that large commercial banks do not contain, it could draft more targeted financing contracts for local small, medium and micro-sized enterprises . Back in 1998 , Laurence h. Meyer's [9] research already showed that when they chose serving banks, they often chose ones within 5 miles. In China, although the business scale of them is small, it is often really frequent . Selecting the nearest bank reduces both time and transportation cost, thus city commercial bank could charge higher financial service fees and achieve a win-win outcome .

\subsection{Consideration about cooperation with city commercial banks from other regions}

What exists between bank and enterprise is a dual promotive relation. When it comes for small, medium and micro-sized enterprises to select the partner, it is unnecessarily limited in their own region, instead they could select the most suitable one after careful compare . Just as how city commercial banks from distinct regions apply different products to meet their need for capital , small, medium and micro-sized enterprises could choose the appropriate product for their own to ensure healthy growth .

\subsection{Switch traditional development concept, be more creative}

Most small, medium and micro-sized enterprises in China, are restricted by being easily satisfied, as well as conservative develop concept, and consequently lack motivation to innovate and always get stuck in a passive dilemma that leads to bankruptcy. Thus, while city commercial banks, with whom small, medium and micro-sized enterprises keep in most frequent contact, are seeking to raise their creative capacity, it is essential for they to do the same, try to be more capable of creating, shatter the stubborn develop concept, get in touch with more brand-new financial products, explore fresh measures for financing and become resistant against risks .

\subsection{Organize employee train, cultivate specialized professionals}

The ever-growing of financial business and ceaseless revolutions of city commercial banks ask small, medium and micro-sized enterprises to catch up, especially in terms of training employees [10], since professional employees are so integral in business communication with city commercial banks and negotiating any other services . Furthermore, management of enterprises could also attend those entrepreneur trains organized by government .

\subsection{Establish the correct financing concept, avoid random financing}

Given the deficiency of ability of risk protection, it is more critical for small, medium and micro-sized enterprises to adopt fitting financing plans depending on their own qualities, and not just finance randomly . Like city commercial banks performing targeted services, they should elaborate accurate development reports about themselves so that city commercial banks would be better informed with exact situation in order to avoid financing risks .

\section{Conclusion}

After the epidemic, the economy of China waits for recovery . The government work report of " two 
sessions " of 2021 put the GDP objective aside , and concentrate on the recovery of economy by playing safe . City commercial bank has carried an indispensable responsibility for growth of small , medium and micro-sized enterprises and regional economy . There is no way to neglect those present problems of city commercial bank, and we need to seek for internal causes to solve them , intent for external management innovation and reach for the optimal utility . As a result, based on the develop orientation of city commercial banks, improving the financing-difficulty issue is the first priority and most necessary task .

\section{Acknowledgments}

Project of National College Students' Innovation and Entrepreneurship Training Program of Inner Mongolia University, Project No .202010126014, Project Name: Research on asset securitization based on block chain technology.

\section{References}

1. Meng Yue, Tax paying, 97-98+101(2017)

2. Liangsarina, Market modernization 24, 107-108(2017)

3. Minfeng Lu , Zhenguo Li , Huabei Finance , 24-30+54(2015)

4. Fangfang Dai , Xiaolian Xiong, Journal of Financial Development Research , 5-12(2018)

5. Jinzhong Chen, China Finance, 30-31(2005)

6. Xiaoping $\mathrm{Wu}$, Huabei Finance, 24-28+33( 2017 )

7. Kai Liu , Hebei Finance 07, 54-56(2017)

8. Yihong Chen, South China Finance, 97-102(2015)

9. Laurence, $\mathrm{H}$, Meyer, Journal of Banking \& Finance, (1998)

10. Yunbing Liu , Qiang Zhang , Marketing Research , 73(2015) 